\title{
膨張材を用いたコンクリートのクリープ性状に関する研究 A STUDY OF CREEP BEHAVIOUR OF CONCRETE USING EXPANSIVE ADMIXTURE
}

\author{
百 瀬 晴 基*, 閑田徹志**, 溝㴊 利 明***, 三橋博三**** \\ Haruki MOMOSE, Tetsushi KANDA, Toshiaki MIZOBUCHI \\ and Hirozo MIHASHI
}

\begin{abstract}
This paper aims at clarifying creep behavior of concrete involving expansive (expansive concrete) additive in early age. This clarification is achieved via proposing a new creep model for expansive concrete based on observation in early age strain behavior. This model is verified using compressive early age creep experiment for expansive concrete, in which ages at loading are varied in 0.5,1.0 and 2.0 day. The experimental results are reasonably reproduced, and the accuracy of the proposed model is demonstrated. Finally, the proposed model is found to be utilized for quantitatively evaluating chemical pre-stress generated in restrained expansive concrete elements, which is very effective to control shrinkage cracking in reinforced concrete structural elements.
\end{abstract}

Keywords: Concrete, Expansive Additive, Shrinkage Reducing Admixture, Creep コンクリート, 膨張材, 収縮低減凩, クリープ

1. はじめに

建築物の高耐久性化に対する社会的要求から， R C 造構造物の耐 久性に大きな影響を与える収縮ひび割れを低減し定量的に制御す る技術への需要は極めて高い。収縮ひび割れを低減する手法として, 石灰岩を使用するなど材料・調合を検湃し収縮量を低減する方法, 打設工区を縮小するなど拘束度を低減する方法, 鉄筋量を増しひび 割れ幅を抑制する方法など, 数多くの手法が存在する ${ }^{1) 。 こ れ ら の ~}$ 対策手法は経験的に効果が高いことが知られているものの, その効 果は同じ指標で定量的に明らかになっていない。また,これらの対 策手法は実構造物における定量的な効果の予測が難しく, 合理的な 判断から実構造物に適用されるに至っていない2)。

このような背景のもと, 著者らは膨張材や収縮低減剤などひび割 れ低減に有効な材料のひび割れ抵抗性を評価することを目的として， これらの材料を混入したコンクリートについて一軸拘束実験を行い 独自の評価指標を導入してひび割れ抵抗性を定量的に評価した ${ }^{3)}$ 。 その結果, 膨張材と収縮低減剤, 膨張材と低熱ポルトランドセメン トを併用したコンクリートが, 高いひび割れ抵抗性を有しているこ とが確認でき，実躯体に扔いてもそのひび割れ抵抗性が高いことを 実証している1)，5)。このような収縮ひび割れ抵抗性の高いコンクリ
ート(以下，本コンクリートと略称する)の寒構造物への適用に関し て定量的な判断を実施するためには，本コンクリートの実躯体にお けるひび割れ抵抗性について, 定量的な評価および予測が不可欠で あるといえる。

しかしながら，本コンクリートに代表される膨張材を混入したコ ンクリートにおけるひび割れ低減効果を予測するためには, 最大の 特徴である材齢初期の膨張によるケミカルプレストレスを定量的 に予測する必要があるが，現状ではこの予測方法は確立されている とは言い難い。この予測に関連した知見として, 辻等は拘束の程度 によらず膨張材の仕事量は一定であるとする仕事量一定則を提案 しており，この手法は広く知られている ${ }^{6)}$ 。しかし，この仕事量一 定則は拘束体である鋼材量が入力項目の一つであり，外部拘束が支 配的である建築構造物では外部拘束による拘束度が自明でないた め, 仕事量一定則を適用する事は難しい。仕事量一定則以外の々ミ カルプレストレスの予测手法として佐藤等は線形クリープ則を用 いた态力解析手法を検討している。この手法を用いることにより， 膨張材を混入した高強度コンクリートの発生応力を精度良く予測 でき, 結合材が強固である高強度域では線形クリープ則が適用でき る事を証明しているものの, 普通強度域における検証はされていな
* 鹿島技術研究所建築生産グループ 研究貣

** 鹿島技術研究所建築生産グループ 上席研究員・Ph. D

*** 法政大学工学部都市環境デザイン工学科 教授・博士 (工学)

**** 東北大学大学院工学研究科都市 $\cdot$ 建築学尃攻 教授・工博
Research Engineer, Kajima Tech. Research Institute

Supervisory Research Engineer, Kajima Tech. Research Institute, Ph. D.

Prof., Department of Civil and Environmental Engineering, Hosei University, Dr. Eng.

Prof., Dept. of Architecture and Building Science, Tohoku University, Dr. Eng. 
W7)。

本論では，本コンクリートのひび割れ抵抗性を定量的に評価・予 測することを目的として，膨張材を混入したコンクリートのクリー プ式を提案すると共に，普通強度域における Step by Step 法によ る応力解析手法の妥当性を検証する。クリープ式を提案するにあた って，本コンクリートの膨張過程におけるクリープ特性を把握する ベく，若材齢時のクリープ実験を行った。さらに，拘束度を変化さ せた複数の一軸拘束試験体を作製し，提案したクリープ式を用いて Step by Step 法による応力解析を実施した。

\section{2. 若材齢時におけるクリープ実験概要}

\section{1 実験要因}

実験要因と水準を表ー 1 に示す。本実験では，表ー 1 に示す計 9 ケースについて，圧縮クリープ実験を実施した。実験要因は，コン クリート種類と載荷材齢の 2 要因とした。コンクリート種類は，膨 張材と低熱ポルトランドセメントを併用したコンクリート（以下， LE), 膨張材と収縮低減剤を併用したコンクリート(以下，NES)，比 較対象である普通コンクリート(以下，N)の 3 水準とした。載荷材 齢は，膨張材の膨張過程におけるクリープ特性を把握するべく，始 発を 0 日とした $0.5 ， 1.0 ， 2.0$ 日の 3 水準とした。

\section{2 使用材料及び調合}

調合表を表 -2 に，使用材料を表一 3 に示す。セメントは普通ポ ルトランドセメント，低熱ポルトランドセメントを使用し，粗骨材 は硬質砂岩を使用した。膨張材はエトリンガイト・石灭複合系の低 添加型膨張材，収縮低減剤は低級アルコール系を使用した。調合は， 水結合材比 $45 \%$ ，単位水量 $170 \mathrm{~kg} / \mathrm{m}^{3}$ ，膨張材添加量 $20 \mathrm{~kg} / \mathrm{m}^{3}$, 収縮低 減剂添加量 $6 \mathrm{~kg} / \mathrm{m}^{3}$, 空気量 $4.5 \%$ とした。また, 膨張材はセメント量 の外割り，収縮低減剂は単位水量の内割りとした。

\section{3 実験方法}

試験体詳細図を図ー1に示寸。圧縮クリープ実験は JIS 原案(コン クリートの压縮クリープ試験方法(案))に準拠した ${ }^{8)}$ 。1 調合につき $\phi 150 \times 300 \mathrm{~mm}$ の載荷試験体を 6 体，鉄筋比 $0.1 \%$ のネジ鉄筋で拘束 した $\phi 150 \times 300 \mathrm{~mm}$ の無載荷試験体を 2 体作製した。始発を 0 日とし た材齢 0.5 日時点において全ての試験体を脱型し， $20^{\circ} \mathrm{C}$ 封絾養生と した。載荷試験体は 1 水準につき 2 体づつ, 載荷材齢時圧縮強度の 0.3 倍の応力で載荷した。ひずタ計測は変位計を用いて試験体の長 さ変位を測定し，長さ変化を試験体長さで除した值を試験体のひず みとした。

これまでの研究において，膨張材を混入したコンクリートでは， 無拘束試験体で発生する膨張ひずみが型枠等の微小な拘束の影響 によりバラツキが大きくなるため，膨張ひずみが安定する鉄筋比 $0.1 \% の$ 微拘束試験体のひずみを自由ひずみとする事を提案してい る ${ }^{9)}$ 。压縮クリープ試験 JIS 原案では無載荷試験体として無拘束試 験体を用いるが，今回は膨張材を混入したコンクリートを対象とし ているため, 鉄筋比 $0.1 \%$ 微拘束試験体を無載荷試験体とした。ま た，始発を 0 日として材齢を換算するため，凝結試験 (JIS A 1108) を行い始発時間と終結時間を測定した。

また，1 調合につき $\phi 150 \times 300 \mathrm{~mm}$ の試験体を 18 体作製し，それ ぞれ材齢 $0.5 ， 1.0 ， 2.0 ， 7 ， 14 ， 28$ 日において，3 体づつ圧縮強度 試験(JIS A 1108) 及びヤング係数試験 (JIS·A 1149)に供した。クリ
一プ実験に供する試験体と同样に，始発を 0 日とした材齢 0.5 日時 点において全ての試験体を脱型し，その後 $20^{\circ} \mathrm{C}$ 封絾養生とした。

\section{3. クリープ実験結果および考察}

3.1 クリープ係数の算定方法

クリープ実験結果の評価值として，CEB-FIP1990 式で定義されて いるクリープ係数(材齢 28 日の弾性ひずみに対するクリープひずみ

\section{表一 1 実験要因と水準}

\begin{tabular}{|c|c|c|c|c|c|}
\hline NO & 祀昂 & セメント & 趾張材 & 収蜼低娍剮 & 載荷材粭 \\
\hline 1 & $L E-0.5$ & \multirow{3}{*}{$\begin{array}{c}\text { 低整 } \\
\text { ポルトラント } \\
\text { セxント }\end{array}$} & \multirow{3}{*}{$20 \mathrm{~kg} / \mathrm{m}^{3}$} & \multirow{3}{*}{-} & 0.5 日 \\
\hline 2 & $\mathrm{LE}-1.0$ & & & & 1.0 日 \\
\hline 3 & LE- -2.0 & & & & $2.0 日$ \\
\hline 4 & NES -0.5 & \multirow{3}{*}{$\begin{array}{c}\text { 音通 } \\
\text { ポルトラント } \\
\text { セxント }\end{array}$} & \multirow{3}{*}{$20 \mathrm{~kg} / \mathrm{m}^{3}$} & \multirow{3}{*}{$6 \mathrm{~kg} / \mathrm{m}^{3}$} & $0.5 \mathrm{日}$ \\
\hline 5 & NES -1.0 & & & & 1.0 日 \\
\hline 6 & NES-2.0 & & & & 2.0 日 \\
\hline 7 & $\mathrm{~N}-0.5$ & \multirow{3}{*}{$\begin{array}{c}\text { 萧通 } \\
\text { ポルトラント } \\
\text { セxント }\end{array}$} & \multirow{3}{*}{ - } & \multirow{3}{*}{ - } & 0.5 日 \\
\hline 8 & $\mathrm{~N}-1.0$ & & & & 1.0 日 \\
\hline 9 & $\mathrm{~N}-2.0$ & & & & 2.0 日 \\
\hline
\end{tabular}

表 -2 調合表

\begin{tabular}{|c|c|c|c|c|c|c|c|c|}
\hline \multirow[b]{2}{*}{ 壾每 } & \multirow[b]{2}{*}{$\mathrm{W} / \mathrm{B}(\boldsymbol{x})$} & \multirow[b]{2}{*}{$s / a(x)$} & \multicolumn{6}{|c|}{ 草位量 $\left(\mathrm{kg} / \mathrm{m}^{3}\right)$} \\
\hline & & & 水 & 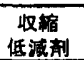 & セxント & 䑀張材 & 山㱠 & 碎石 \\
\hline$L E$ & 45.0 & 45.6 & 170 & $\overline{-}$ & 358 & $\overline{20}$ & 780 & $\overline{962}$ \\
\hline NES & 45.0 & 45.5 & 170 & 6 & 358 & 20 & 775 & 962 \\
\hline $\mathbf{N}$ & 45.0 & 45.5 & 170 & - & 378 & - & 774 & 962 \\
\hline
\end{tabular}

表 -3 使用材料

\begin{tabular}{|c|c|c|}
\hline 程類 & 村料名 & 慗度 $\left(\mathrm{g} / \mathrm{cm}^{3}\right)$ \\
\hline \multirow{2}{*}{ セメント } & 章通ポルトランドセメント & 3.16 \\
\hline & 低棨ポルトランドセメント & 3.22 \\
\hline 枟材 & エトリンガイトー石灰梅合系 & 3.20 \\
\hline 触骨材 & 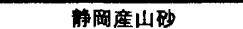 & 2.56 \\
\hline 粗骨材 & 奥多庵產硬翼砂岩 & 2.65 \\
\hline 収樎低娍靗 & 低級アルコール系 & 1.00 \\
\hline 高性能AE減水望 & ポリカルボン酸系 & 1.00 \\
\hline
\end{tabular}

表 -4 強度試験結果

\begin{tabular}{|c|c|c|c|c|c|c|}
\hline \multirow{2}{*}{$\begin{array}{l}\text { 林龄 } \\
\text { (日) }\end{array}$} & \multicolumn{3}{|c|}{ 珐宿強度 $\left(\mathrm{N} / \mathrm{mm}^{2}\right)$} & \multicolumn{3}{|c|}{ ヤング係数 $\left(\times 10^{3} \mathrm{~N} / \mathrm{mm}^{2}\right)$} \\
\hline & LE & NES & $\mathrm{N}$ & LE & NES & $\mathbf{N}$ \\
\hline 0.5 & 3.1 & 5.2 & 6.5 & 3.8 & 12.0 & 13.2 \\
\hline 1 & 6.5 & 12.9 & 13.2 & 12.6 & 19.6 & 19.9 \\
\hline 2 & 10.3 & 21.1 & 21.9 & 16.1 & 25.1 & 24.5 \\
\hline 7 & 22.8 & 35.3 & 37.5 & 24.7 & 28.7 & 29.1 \\
\hline 14 & 29.3 & 41.8 & 43.1 & 27.4 & 31.0 & 30.6 \\
\hline 28 & 39.1 & 45.6 & 47.8 & 30.1 & 32.4 & 31.8 \\
\hline
\end{tabular}

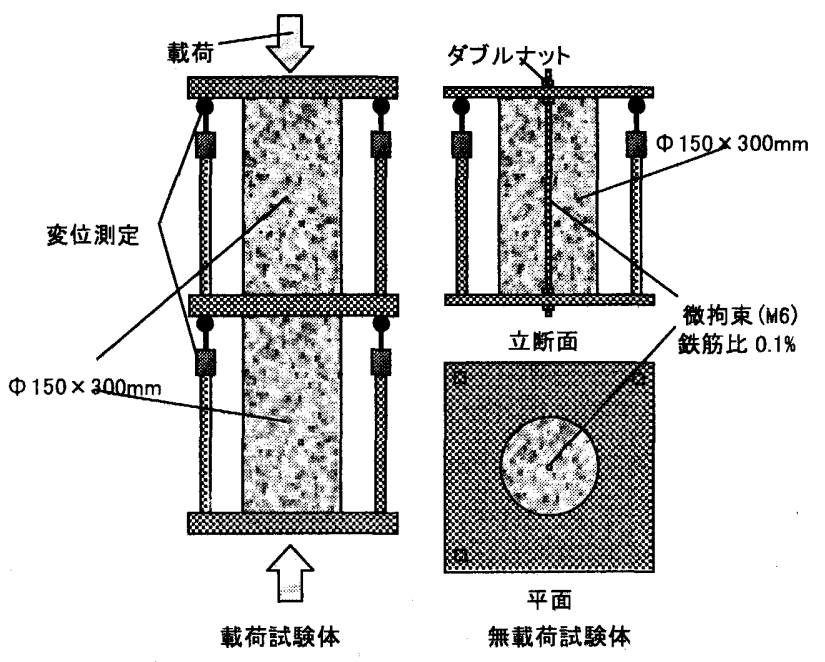

図-1 クリープ試験体詳細 
の比) ${ }^{10)}$, ACI209 式で定義されているクリープ係数(載荷時の弾性ひ ずみに対するクリープひずみの比) ${ }^{11)}$ ，土木学会式で定義されている スペシフィッククリープひずみ(載荷時の応力に対するクリープひ ずみの比) ${ }^{12)}$ ，などが挙げられる。本実験では, CEB-FIP1990 式で定 義されるクリープ係数を用いることとした。クリープ係数およびク リープひずみの算出は以下のように表現される。

$$
\begin{aligned}
& \phi\left(t, t_{0}\right)=-\varepsilon_{c c r e}\left(t, t_{0}\right) /\left(\sigma_{c}\left(t_{0}\right) / E_{c}(28)\right) \\
& \varepsilon_{c \text { cre }}\left(t, t_{0}\right)=\varepsilon_{c}\left(t, t_{0}\right)-\varepsilon_{c s h}\left(t, t_{0}\right)
\end{aligned}
$$

ここで, $\phi\left(t, t_{0}\right), \quad \varepsilon_{c c r e}\left(t, t_{0}\right), \quad \sigma_{c}\left(t_{0}\right), \quad E_{c}(28), \quad \varepsilon_{c}\left(t, t_{0}\right), \quad \varepsilon_{c s h}\left(t, t_{0}\right), \quad t, t_{0}$ はそれぞれクリープ係数，クリープひずみ，載荷応力，材齢 28 日 のコンクリートのヤング係数, 載荷試験体のひずみ, 無載荷試験体
のひずみ，材齢，载荷材齢を表す。

\section{2 クリープ実験結果}

強度試験結果を表 -4 に, 各ひずみ結果を図ー2に,クリープひ ずみ結果を図ー3に，クリープ係数結果を図ー4に示す。図ー4か

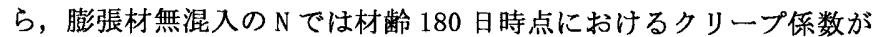
載荷材㱓によらず 2 前後であるのに対し, 膨張材を混入した LE- 0.5 では $11, \mathrm{LE}-1.0$ では 4.5, NES-0.5 では 4.5 程度と $\mathrm{N}$ を大きく上回 る值を示すことが分かった。また，載荷材齢が進むに従いその差は 减少し, 載荷材歯 2.0 日ではクリープ係数に与える調合の影響は認 められなかった。

この膨張コンクリートの若材㛔時におけるクリープ係数が増大 する原因として, 膨張期間における膨張ひずみが影響していると考

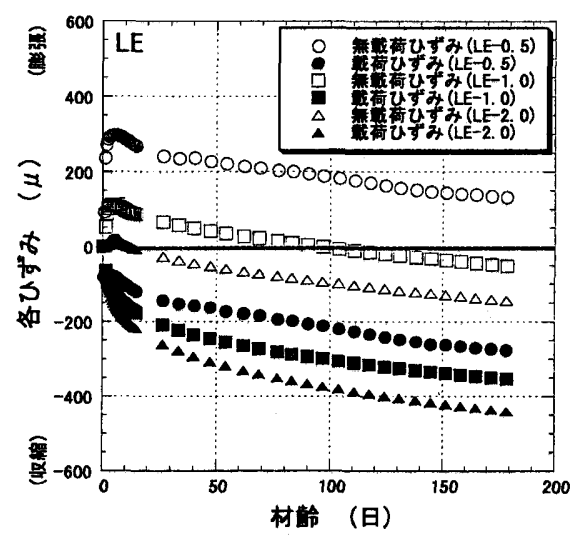

図一2,a 各ひずみ結果 (LE)

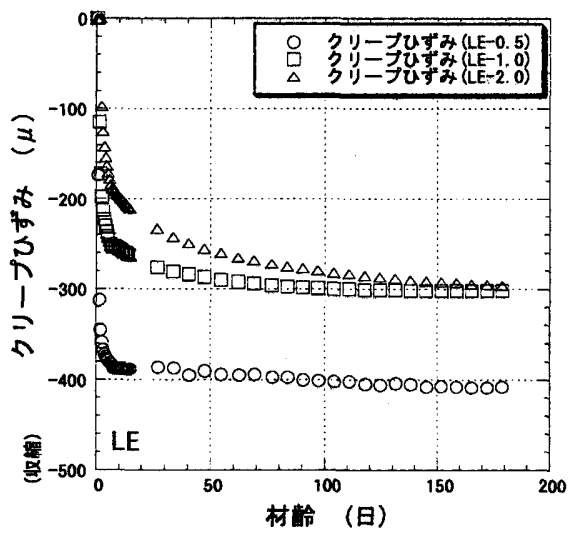

図ー3.a クリープひずみ結果 (LE)

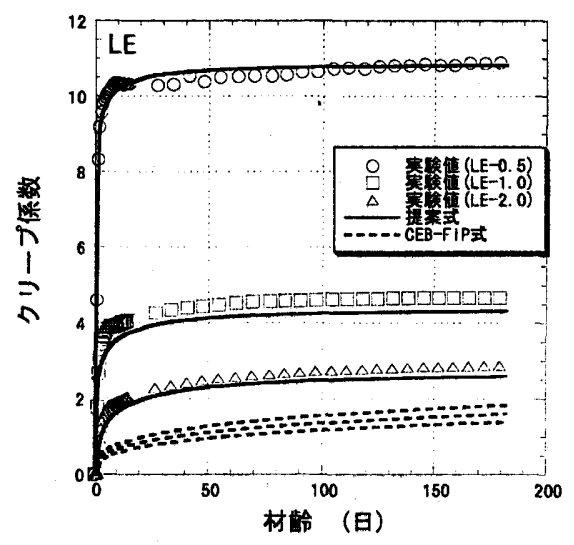

图一 4.a クリープ係数 (LE)

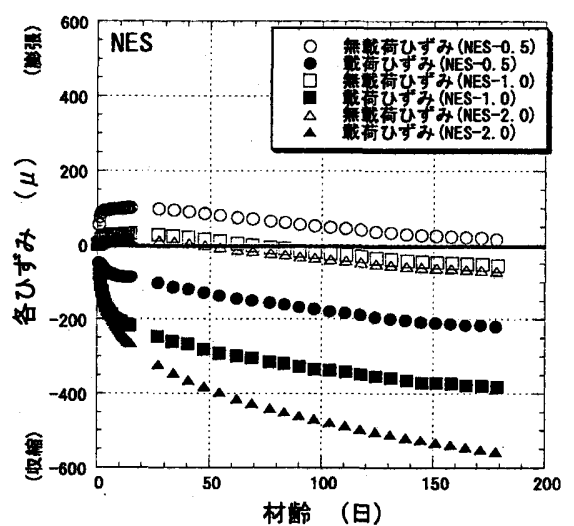

図ー2.b 各ひずみ結果 (NES)

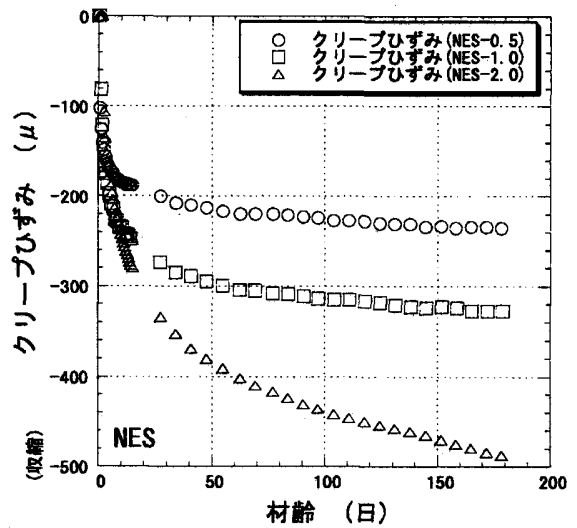

図ー3.b クリープひずみ結果 (NES)

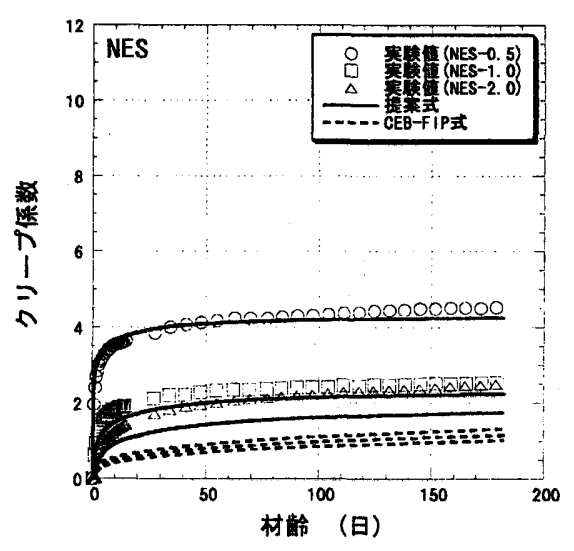

図ー4.b クリープ係数 (NES)

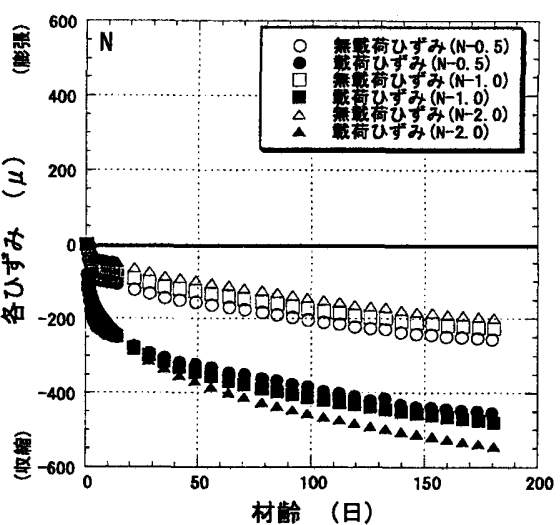

図一2.c 各ひずみ結果 $(N)$

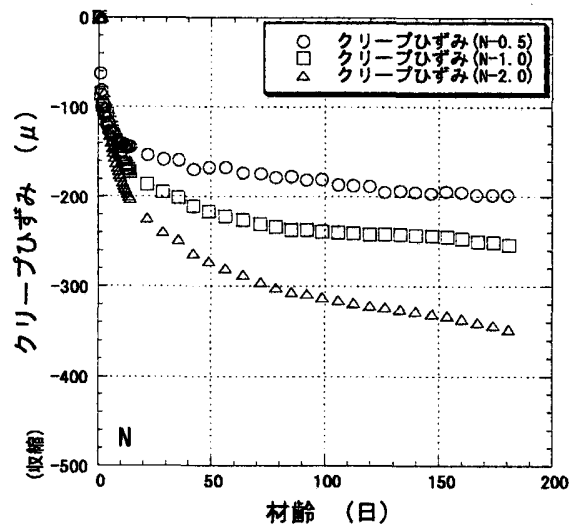

図一3.c クリープひずみ結果 $(\mathrm{N})$

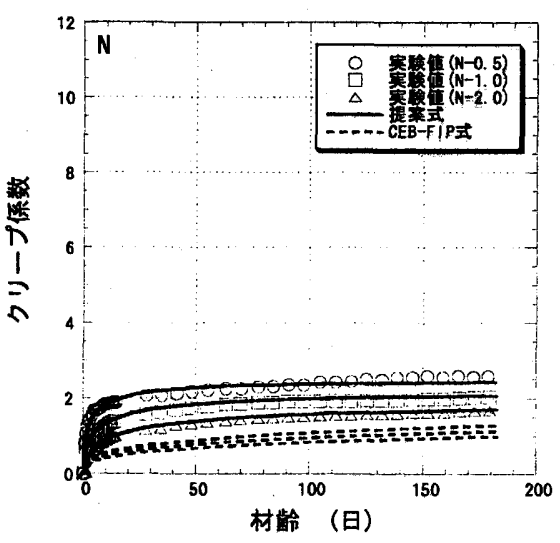

図-4.c クリープ係数 $(N)$ 
えられる。図一 5 は, 材齢 $t_{0}$ において, 圧縮方向に一定応力を載荷 した場合のコンクリートひずみの模式図である。普通コンクリート のクリープひずみの定義では, 載荷ひずみ $\left(\varepsilon_{c N R}\right)$ と無載荷ひずみ $\left(\varepsilon_{c s h}\right.$ $\left.{ }_{N R}\right)$ との差をクリープひずみ $\left(\varepsilon_{c \text { cre } N R}\right)$ としている。膨張コンクリートに おいても, 膨張が安定した後は, 普通コンクリートと同様である。 しかしながら，載荷材齢が膨張期間中である場合，無載荷ひずみ( $\varepsilon_{c}$ $s h E X)$ 符号が逆転するため, 載荷ひずみ $\left(\varepsilon_{c E X}\right)$ と無載荷ひずみ $\left(\varepsilon_{c h} \operatorname{EX}\right)$ との和がクリープひずみ $\left(\varepsilon_{\text {c cre } E X}\right)$ となる。膨張コンクリートの若材齢 時のクリープが大きな值を示す原因は, 無載荷試験体で認められる 膨張挙動が載荷試験体では認められず, 膨張する無載荷ひずみ( $\varepsilon_{c s h}$ $\left.{ }_{E X}\right)$ がクリープひずみに含まれる事によるものと推測される。

本実験においても, 図一2の無載荷ひずみ結果から, LE では材 歯 1.0 日, NES では 0.5 日まで膨張期間であること, 図ー 4 のクリ ープ係数結果から，LEでは 1.0 日，NES では 0.5 日までクリープ係 数が極度に大きいことが確認できることから，この仮説は一定程度 の信頼性を有していると考えられる。

\section{3 膨張材を混入したコンクリートのクリープ式の提案}

Step by Step 法による応力解析を実施することを念頭に，クリー プ実験結果を数式化し，膨張材を混入したコンクリートのクリープ 式を提案する。図ー4から, 既存の予測式である CEB-FIP1990 式は, 実験結果を過小評価しており, 膨張コンクリートの特殊なクリープ 挙動を再現できていないが，今回提案したクリープ式は，既存の CEB-FIP1990 式に比べて精度良く実験値を再覞できている。なお， 提案するクリープ式は, 膨張コンクリートの若材齢クリープが見掛 け上増大する実験結果を対象に，玩象論的視点から数式化したもの である。したがって，この提案式は，物理的メカニズムに立脚して いない経験式として位置づけられ，得られるクリープ係数について は見掛けの值であることに留意が必要である。

本式は，(3)式に示すようにクリープ試験における無載荷試験体の 膨張ひずみによるクリープ(以下，膨張クリープ)と，載荷試験体に よる通常のクリープ(以下，載荷クリープ)は別の機構であると仮定 し，それぞれを足し合わせた形とした。

$$
\phi\left(t, t_{0}\right)=\phi_{\infty E X} \times \beta_{c E X X}\left(t, t_{0}\right)+\phi_{\infty} C E B \times \beta_{c E E B}\left(t, t_{0}\right)
$$

ここで, $\phi\left(t, t_{0}\right), \quad \phi_{\infty}$ EXX $, \quad \beta_{C E X X}\left(t, t_{0}\right), \quad \phi_{\infty}$ CEB,$\quad \beta_{C C E B}\left(t, t_{0}\right)$ はそれぞ れクリープ倸数, 膨張クリープの終局クリープ倸数, 膨張クリープ の速度項, 載荷クリープの終局クリープ係数, 載荷クリープの速度 項を表す。

載荷クリープには，既存の予測式である CEB-FIP1990 式を用いる こととした。しかしながら，図ー4から，CEB-FIP1990 式は，膨張 材を混入した LE およびNES だけでなく，Nにおいても精度が低いこ とが確認できる。日本コンクリート工学協会自己収縮委員会では, CEB-FIP1990 式は, クリープの進行速度が遅く, 若材㱓のクリープ 係数を精度良く予測できないことを示唆しており，CEB-FIP1990 式 を修正した式(以下，JCI 式)を提案している ${ }^{13)}$ 。この式は, 終局ク リープ係数 $\phi_{\infty}$ と, クリープの進行速度を決定する $\beta_{I I}$ を, 圧縮強度 もしくはヤング係数に依存する值とし, 高強度コンクリートの若材 齢クリープを精度良く再現している。

膨張材無混入の N, 膨張挙動が安定した LE-2.0, NES-1.0, NES-2.0 について, 最小 2 乗法により $\phi_{\infty}$ と $\beta_{I I}$ を同定した。同定した $\beta_{I I}$,

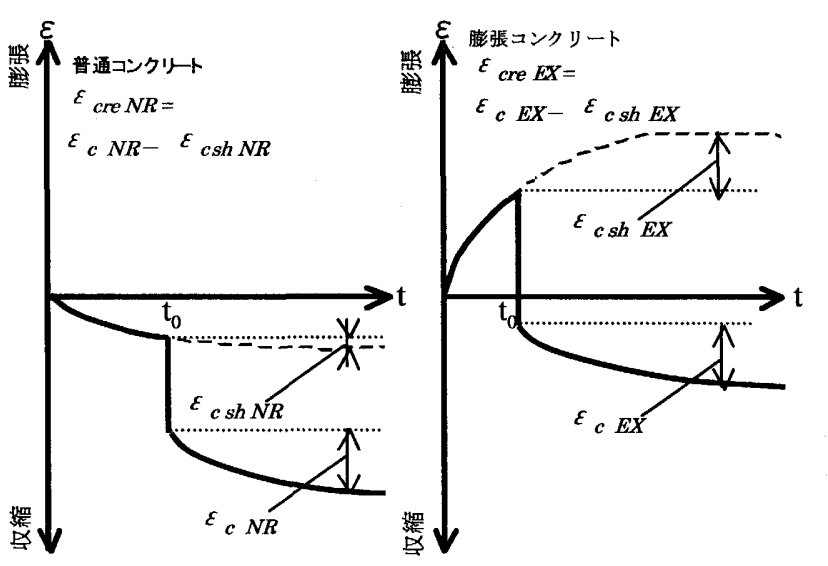

図ー5 クリープひずみ算出方法の概念図

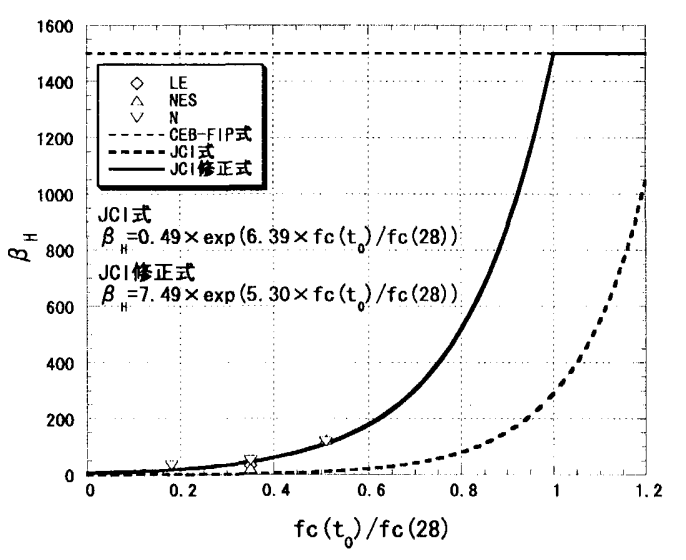

図一6 $\quad \beta_{H}$ の検討

CEB-FIP1990 式の $\beta_{H}$, JCI 式の $\beta_{I I}$ を図ー6に示す。JCI 式は CEB-FIP1990 式に比べて実験值に近い值を示しているものの, 高強 度コンクリートを対象とした式であるため, 普通強度域である本実 験結果とは若干差異が認められる。また，図中に示すように，本実 験結果は, JCI 式を基に最小 2 乗法により定数を修正した式(以下, JCI 修正式)で精度良く数式表現することができる。今回は, 載荷ク リープの進行速度を決定する $\beta_{I I}$ に JCI 修正式を導入した式を用い ることとした。載荷クリープの終局クリープ係数, 載荷クリープの 速度項は以下のように表現される。

$$
\begin{aligned}
& \phi_{\infty C E B}=\phi_{R H} \times \beta\left(f_{c m}\right) \times \beta\left(t_{0}\right) \\
& \beta_{c C E B}\left(t, t_{0}\right)=\left(\left(t-t_{0}\right) / t_{I}\right) /\left(\beta_{H}+\left(t-t_{0}\right) / t_{l}\right)
\end{aligned}
$$

$$
\beta_{H}=7.49 \times \exp \left(5.30 \times f_{c}\left(t_{0}\right) / f_{c}(28)\right)
$$

ここで, $\phi_{R H}, \beta\left(f_{c m}\right), \quad \beta\left(t_{0}\right), f_{c}\left(t_{0}\right), f_{c}(28)$ はそれぞれ乾㠘クリ一 プの影響の項, 圧縮強度の影響の項, 載荷材齢の影響の項, 載荷材 齢 $t_{0}$ における圧縮強度, 材齢 28 日における圧縮強度を表す。

膨張クリープの支配的要因は, 無載荷ひずみの膨張挙動にあると 考え，無載荷ひずみを数式化しクリープ式中に反映させることとし た。膨張クリープの終局クリープ係数, 膨張クリープの速度項は以 ドのように表兒される。

$$
\begin{aligned}
& \phi_{\infty L I X}=\alpha_{1} \times \exp \left(m_{1} \times\left(t_{0}\right)^{m 2}\right) /\left(f_{c}\left(t_{0}\right) / f_{c}\left(t_{1}\right)\right) \\
& \beta_{c E X X}\left(t, t_{0}\right)=\left(\beta_{c E X X}(t)-\beta_{c E X X}\left(t_{0}\right)\right) /\left(1-\beta_{c E X}\left(t_{0}\right)\right)
\end{aligned}
$$




$$
\begin{aligned}
& \beta_{c E X}(t)=1-\exp \left(m_{1} \times(t)^{m 2}\right) \\
& \varepsilon_{c s h}(t)=m_{0} \times\left(1-\exp \left(m_{1} \times\left(t_{0}\right)^{m 2}\right)\right)
\end{aligned}
$$

ここで， $\alpha_{1}$ は膨張クリープの大きさを決定する項， $m_{0}, m_{l}, m_{2}$, は無載荷ひずみの膨張挙動を表す係数を表す。 $m_{0}, m_{1}, m_{2}$, は(10) 式を用いて最小 2 乗法により無載荷ひずみをフィッティングし同 定した。同定した結果, 係数 $\alpha_{1}, m_{1}, m_{2}$ は, LE ではそれぞれ 18. 808, $-1.035,1.948$, NES ではそれぞれ 22.244，-2.978，2.067 の值が得 られた。

\section{4. 拘束度を変化させた一軸拘束実験}

\section{1 実験要因}

普通強度域における Step by Step 法による応力解析手法の妥当 性を検証することを念頭に，解析対象となる実験データを抽出する ことを目的に拘束度を変化させた複数の一軸拘束実験を実施した。

実験要因と水準を表一 5 に示す。本実験では，表一 5 に示す計 5 ケースについて，一軸拘束実験を実施した。実験要因は，拘束度で あり内部鉄筋比 $0.1 ， 0.4 ， 1.0 ４ .0 ８ .0 \%$ 程度の 5 水準とした。

\section{2 使用材料及び調合}

コンクリートは膨張材と低熱ポルトランドセメントを併用した LE とし，クリープ試験体を作製した同じバッチのコンクリートを用 いた。セメントは低熱ポルトランドセメント，粗骨材は硬質砂岩， 膨張材はエトリンガイト・石灰複合系の低添加型膨張材を使用した。 調合は, 水結合材比 $45 \%$, 単位水量 $170 \mathrm{~kg} / \mathrm{m}^{3}$, 膨張材添加量 $20 \mathrm{~kg} / \mathrm{m}^{3}$, 空気量 $4.5 \%$ とした。

\section{3 実験方法}

試験体詳細図を図ー7に示す。一軸拘束実験は, 膨張コンクリー トの拘束膨張及び収縮試験方法B法(JIS A 6202) に準拠した。試験 体数は 1 ケースあたり 3 体とし，始発を 0 日としてひずみゲージに より鉄筋のひずみ量を計測した。試験体の養生は $20^{\circ} \mathrm{C}$ 封絾養生とし た。なお，コンクリートの内部発生応力は，(11)式により鉄筋のひ ずみ量から計算によって求めた。（11）式は，力の验り合い式から内 部鉄筋のひずみとコンクリートのひずみが等しいと仮定し求めた。

$$
\sigma_{c}(t)=\varepsilon_{s}(t) \times E_{s} \times A_{s} / A_{c}
$$

ここで， $\sigma_{c}(t), \varepsilon_{s}(t), E_{s}, A_{s}, A_{c}$ はそれぞれ材齡 $t$ 日におけるコン クリートの応力, 材齢 $t$ 日における鉄筇のひずみ，鉄筋のヤング係 数，鉄筋の断面積，コンクリートの断面積を表す。本実験では， $E_{s}$ は $210000 \mathrm{~N} / \mathrm{mm}^{2}$ と仮定した。

\section{4 実験結果}

一軸拘束実験結果を図ー8に示す。図ー8から，各試験体のひず み挙動は内部鉄筇比が大きくなる程, 最大膨張量が小さい結果とな った。各試験体の応力実験結果は, 材齢 0 日直後から膨張材の影響 により圧縮応力が発生し, 内部鉄筋比が大きい程, 最大圧縮応力が 大きい結果となった。

\section{5. 一軸拘束実験における解析的検討}

5.） Step by Step 法による解析手法

Step by Step 法は, クリープ進行曲線を用いて任意の時刻分割に 従い，時間間隔毎の変化応力による変化ひずみを求積していく解析
法である。タイムインターバルの増分応力を加算している点では増 分法と同じだが, Step by Step 法は各インターバルの応力緩和の時 間的変化を考虑できる点が異なる。Step by Step 法の数式表現を

\begin{tabular}{|c|c|c|c|c|c|}
\hline 配昂 & セメント & 琏張材 & 収縮低隇敖 & 内部鉄筋 & 内部铁筋比 \\
\hline LE-0.1\% & \multirow{5}{*}{$\begin{array}{c}\text { 低熱 } \\
\text { ポルトランド } \\
\text { セメント }\end{array}$} & \multirow{5}{*}{$20 \mathrm{~kg} / \mathrm{m}^{3}$} & \multirow{5}{*}{ - } & M4 & $0.10 \%$ \\
\hline LE- $0.4 \%$ & & & & M8 & $0.41 \%$ \\
\hline LE-1.0\% & & & & M12 & $0.93 \%$ \\
\hline LE-4.0\% & & & & M24 & $3.82 \%$ \\
\hline LE-8.0\% & & & & M33 & $7.41 \%$ \\
\hline
\end{tabular}
（12）～(15) 式に示す ${ }^{7)}$ 。本解析では，鉄筋比 $0.1 \%$ 試験体におけ 表 -5 実験要因と水準

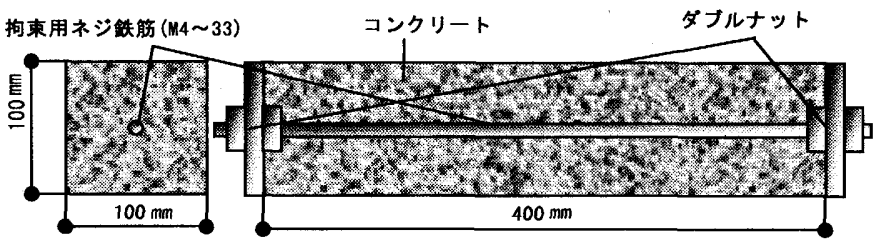

\begin{tabular}{|c|c|c|c|c|c|}
\hline 項目 & \multicolumn{2}{|c|}{ 記号 } & 项目 & \multicolumn{2}{|c|}{ 記昂 } \\
\hline \multirow{3}{*}{ クリープ係数 } & $\alpha_{1}$ & 18.808 & \multirow{3}{*}{ 微拘束ひずみ } & $m 0$ & 528 \\
\hline & $m l$ & -1.296 & & $m I$ & -1.296 \\
\hline & $m 2$ & 1.212 & & $m 2$ & 1.212 \\
\hline \multirow{4}{*}{ 圧狳怕強度 } & $f_{c}(28)$ & 39.1 & \multirow{4}{*}{ ヤング係数 } & $E_{c}(28)$ & 30143 \\
\hline & $s$ & 0.380 & & $S$ & 0.380 \\
\hline & $\alpha_{f}$ & 0.920 & & $\alpha_{E}$ & 0.971 \\
\hline & $t_{f s}$ & 0.127 & & $t_{f s}$ & 0.127 \\
\hline
\end{tabular}

図-7 試験体詳細図

表-6 各係数値及び定数値

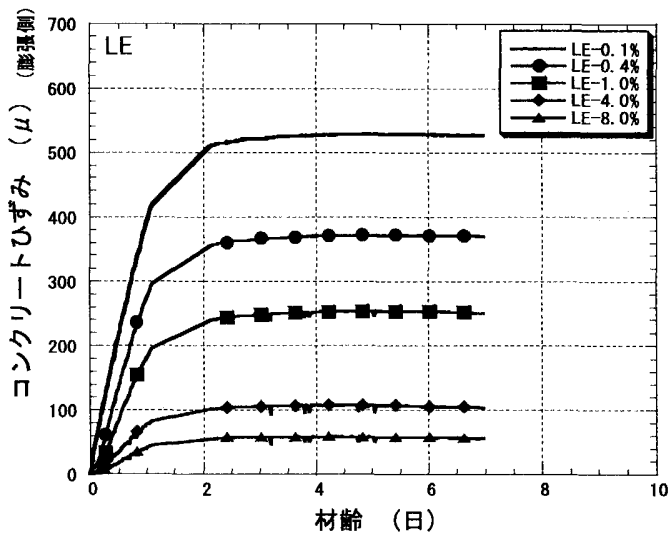

図一8.a Uずみ実験結果

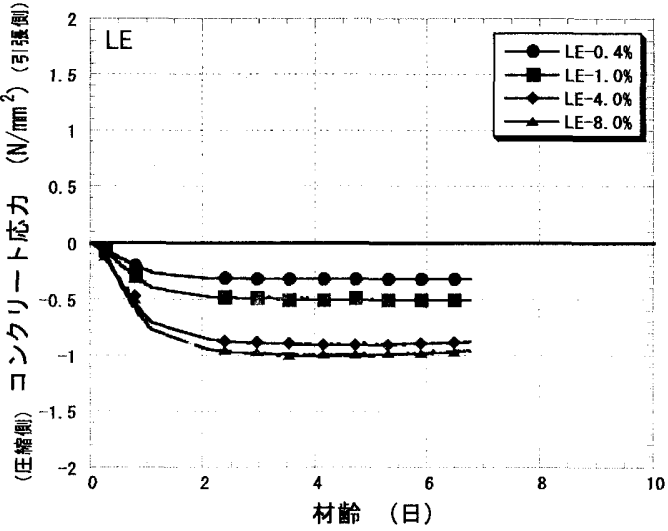

図-8.b 応力実験結果 
るコンクリートのひずみ結果(以下，微拘束ひずみ)をインプットデ 一タとして解析を行なった。

$$
\begin{aligned}
& \sigma_{c}\left(t_{i+1 / 2}\right)=1 / J\left(t_{i+1 / 2}\right) \times\left\{\varepsilon_{c}\left(t_{i+1 / 2}\right)-\varepsilon_{c c r e}\left(t_{i-1 / 2}\right)-\varepsilon_{c s h}\left(t_{i+1 / 2}\right)\right\} \\
& \Delta \sigma_{c}\left(t_{i}\right)=\sigma_{c}\left(t_{i+1 / 2}\right)-\sigma_{c}\left(t_{i-1 / 2}\right) \\
& J\left(t_{i+1 / 2}, t_{i}\right)=1 / E_{c}\left(t_{i}\right)+\phi\left(t_{i+1 / 2}, t_{i}\right) / E_{c}(28) \\
& \varepsilon_{c} \text { cre }\left(t_{i-1 / 2}\right)=\sum_{j=1}^{i-1} \triangle \sigma_{c}\left(t_{j}\right) \times J\left(t_{i+1 / 2}, t_{j}\right)-J\left(t_{i+1 / 2}, t_{i}\right) \times \sigma_{c}\left(t_{i-1 / 2}\right)
\end{aligned}
$$

$\sigma_{c}\left(t_{i+1 / 2}\right):$ ステップ $t_{i+1 / 2}$ でのコンクリート応力

$\varepsilon_{c}\left(t_{i+1 / 2}\right):$ ステップ $t_{i+1 / 2}$ でのコンクリートの実ひずみ

$\varepsilon_{c s h}\left(t_{i+1 / 2}\right):$ コンクリートの微拘束ひずみ

$\phi\left(t_{i+1 / 2}, t_{i}\right):$ ステップ $t_{i}$ で载荷されたステップ $t_{i+1 / 2}$ のクリープ係数

$E_{c}\left(t_{i}\right):$ ステップ $t_{i}$ でのヤング係数

$E_{c}(28):$ 材齢 28 日でのヤング保数

\section{2 増分応力ひずみ関係}

材齢 $t$ における一軸拘束試験体のコンクリートおよび鉄筋の忘力 ひずみ関倸は，それぞれ增分形式で(16)（17）式のように表される。 本実験では, 羕生温度を $20^{\circ} \mathrm{C}$ 一定の条件下としているため, 温度変 化により発生する温度ひずみは考慮しないこととした。

$$
\begin{aligned}
& \Delta \sigma_{c}(t)=E_{c}(t) \times\left(\Delta \varepsilon_{c}(t)-\Delta \varepsilon_{c} c r e(t)-\Delta \varepsilon_{c s h}(t)\right) \\
& \Delta \sigma_{s}(t)=E_{s}(t) \times \Delta \varepsilon_{s}(t)
\end{aligned}
$$

ここで, $\Delta \sigma_{c}(t), E_{c}(t), \Delta \varepsilon_{d}(t), \Delta \varepsilon_{c} c r d(t), \Delta \varepsilon_{c s h}(t)$ はそれぞれコンク リートの応力增分, ヤング係数, 全ひずみ增分, クリープひずみ增 分, 微拘束ひずみ增分を表し, $\Delta \sigma_{s}(t), E_{s}(t), \Delta \varepsilon_{s}(t)$ はそれぞれ鉄筋 の忘力増分，ヤング保数，全ひずみ増分を表す。

\section{3 コンクリートのカ学特性}

クリープ係数は, 3.2 節で提案したクリープ式を用いることとし,

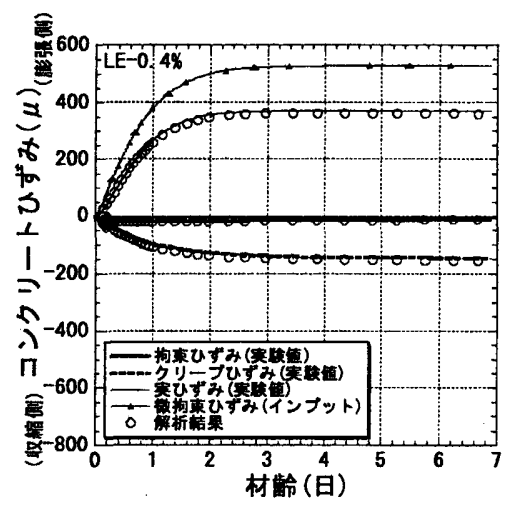

図一9.a 各ひずみ解析結果 (LE-0.4\%)

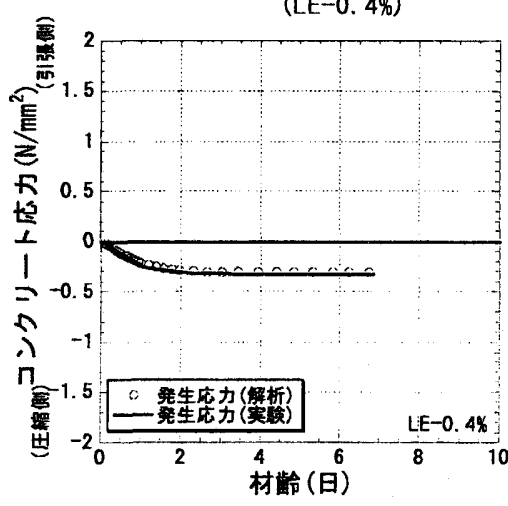

図-10. a 応力解析結果 $(\mathrm{LE}-0.4 \%)$

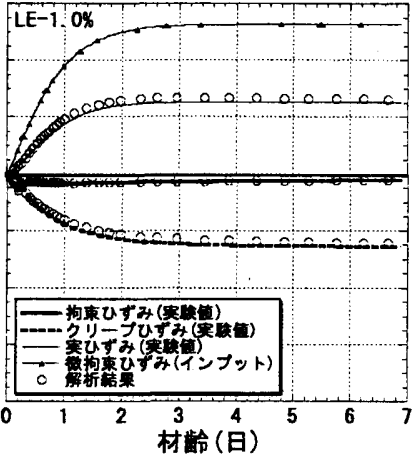

図-9.b

材陪 (日) (LE-1.0\%)

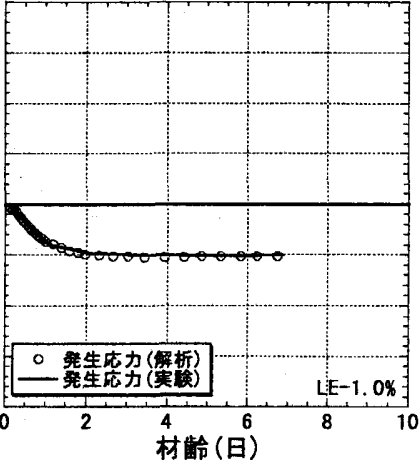

図-10.b 応力解析結果 (LE-1.0\%)
表一6の係数の值を用いた。 $m_{l}, m_{2}$ は微拘束ひずみの膨張举動を表 寸係数であり，今回は精度の良い解析を実施するべく，内部鉄筋比 $0.1 \%$ のずみ結果から同定した值を用いた。

コンクリートの圧縮強度 $f_{c}(t)$, ヤング係数 $E_{c}(t)$ は, CEB-FIP1990 式を用いた ${ }^{10)}$ 。それぞれの数式を以下に示す。

$$
\begin{aligned}
& f_{c}(t)=\alpha_{f} \times f_{c}(28) \times \exp \left(S \times\left(1-\left(\left(28-t_{f_{s}}\right) /\left(t-t_{f s}\right)\right)^{0.5}\right)\right) \\
& E_{c}(t)=\alpha_{E} \times E_{c}(28) \times\left(\operatorname { e x p } \left(S \times\left(1-\left(\left(28-t_{f_{s}}\right) /\left(t-t_{f_{s}}\right)\right)^{0.5}\right)^{0.5}\right.\right.
\end{aligned}
$$

ここに, $t_{f s}$ : 凝結の終結材齢(日)， $\alpha_{f} ， \alpha_{E}$ : 終局值を表す係数， $S:$ 発現の早さを表す係数

\section{4 微拘束ひずみ}

本解析においてインプットデータとなる微拘束ひずみ $\varepsilon_{c s h}$ は, 100 $\times 100 \times 400 \mathrm{~mm}$ の LE-0.1\%のひずみ結果から得るものとした。実験で の養生条件は $20^{\circ} \mathrm{C}$ の封縅養生としている。 $\varepsilon_{c s h}$ は以下の数式を用い て表した。(20)式で実験結果とのフィッティングを行い，表一6の 係数の值を得た。

$$
\varepsilon_{c s h}=m_{0} \times\left(1-\exp \left(m_{l} \times\left(t-t_{s}\right)^{m}\right)\right)
$$

\section{5 解析結果}

Step by Step 法による各ひずみ解析結果を図ー9に, 応力解析結 果を図-10 に示す。図-10 から, 解析結果では全ての試験体にお いて，膨張材のケミカルプレストレスを概旅い精度で再現できて いることが確認できた。このことから，提案した膨張材を混入した コンクリートのクリープ式拉よび本解析手法は妥当であると考え られる。

ケミカルプレストレスの予測手法として良く知られている仕事 量一定則による予測手法と, Step by Step 法による応力解析手法を 比較した ${ }^{6)}$ 。仕事量および仕事量から求める最大圧縮応力の数式表 現を以下に示す。

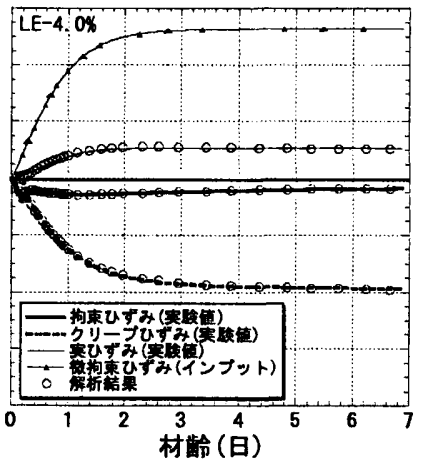

図ー9.c 各ひずみ解析結果 (LE-4. 0\%)

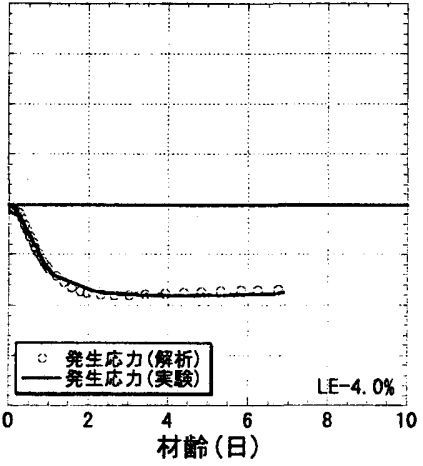

図-10.c 応力解析結果 (LE-4.0\%)

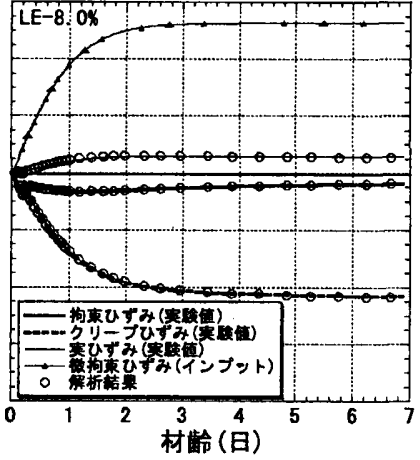

図-9.d 各ひずみ解析結果 (LE-8.0\%)

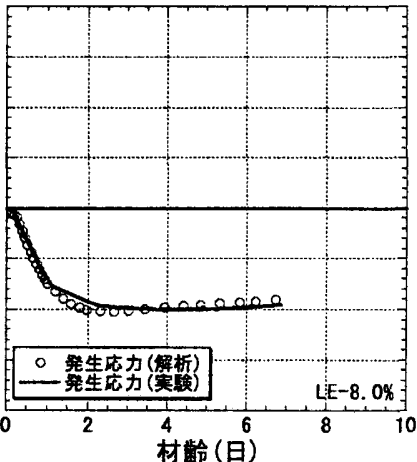

図-10. d 応力解析結果 (LE-8.0\%) 


$$
\begin{aligned}
& U=0.5 \times p \times E_{s} \times\left(\varepsilon_{s c p}\right)^{2} \\
& \sigma_{c p a}=\left(2 \times p \times E_{s}\right)^{0.5} \times(U)^{0.5}
\end{aligned}
$$

ここで, $U, p, E_{s}, \varepsilon_{s}$ cp， $\sigma_{c p a}$ はそれぞれ膨張コンクリートが なす仕事量, 拘束鋼材比, 鉄筋のヤング係数, 拘束鋼材の伸びひ ずみ，ケミカルプレストレスを表す。

実験結果から算定した仕事量を図ー11に示す。今回は, LE-1.0\% の実験結果から算定した仕事量を用いて, その他の試験体におけ る最大压縮応力を予測した。ケミカルプレストレスの予測結果を 図ー12 に示す。Step by Step 法による応力結果では, 全ての試 験体において膨張材のケミカルプレストレスを概ね良い精度で 予測できているのに対し, 仕事量一定則による予測結果では, 適用 範囲である内部鉄筋比 $(0.67 \sim 4.22 \%)$ において概ね圧縮応力が予測 できているものの, 適用範囲外である LE-8.0\%では寨験值を過大評 価していることが確認できた ${ }^{6)}$ 。

文献 3)では, 水セメント比 $50 \%$ 普通コンクリートに対して, 内 部鉄筋比 $8.0 \%$ 程度の一軸拘束ひび割れ試験を実施しており, その拘 束度は 0.63 であった。文献 14)では, $\mathrm{RC}$ 造建築構造物の壁部の拘 束度は 0.6 程度であり, 基礎梁の拘束がある $1 \mathrm{~F}$ 下層部では 0.9 程 度であると報告しており, 解析対象を $\mathrm{RC}$ 造建築構造物の壁部とし た場合，仕事量一定則の適用範囲外での予測が必要であると考えら れる。

本解析手法の最終的な解析対象は, $\mathrm{RC}$ 造建築構造物の壁・床等を 対象としており, 仕事量一定則によるケミカルプレストレスの予測 は適用範囲外となる可能性が高いことから, 本目的においては Step by Step 法による応力解析手法の方が本コンクリートのひび割れ低 減効果を予測する手法として適していると考えられる。

\section{6. まとめ}

本論では, 膨張材と収縮低减剤, あるいは膨張材と低熱ポルトラ ンドセメントを併用したコンクリートのひび割れ抵抗性を定量的 に評価・予測することを目的として, 膨張材を混入したコンクリー トのクリープ式を提案すると共に, 普通強度域における Step by Step 法による応力解析手法の妥当性を検証した。本研究で得られた 結果を以下に示す。

1) 拘束度を変化させた複数の解析ケースにおいて, 膨張材によるケ ミカルプレストレスを精度良く再現できていることから, 提案し た膨張材を混入したコンクリートのクリープ式および本解析手 法は妥当であると考えられる。

2) 膨張材を混入したコンクリートの膨張期間のクリープ係数は普 通コンクリートに対して最大 5 倍程度と非常に大きく, 載荷材齢 が進むに従いその差は小さくなることが分かった。

3) 膨張材を混入したコンクリートの若材齢のクリープ係数は, CEB-FIP1990 式では再現できないこと, 提案したクリープ式では 概ね精度よく再現できることが確認できた。

4)仕事量一定則を用いたケミカルプレストレスの予測手法は, 適用 範团である内部鋼材量 $0.4 \sim 4.0 \%$ の試験体では, 精度良く発生态 力を予測できているが, 適用範囲外である内部鋼材量 $8.0 \%$ の試験 体では精度の良い予測は難しいことが確認できた。
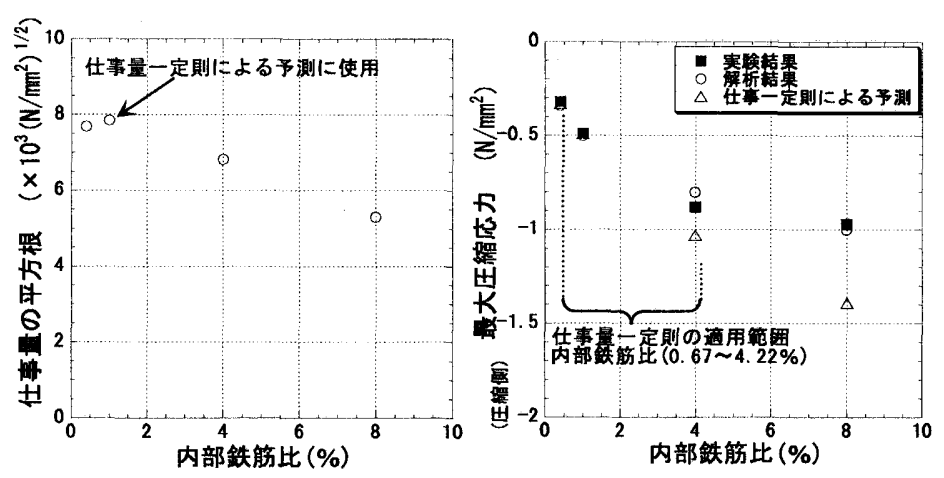

図-11 仕事量の算定 (実験結果) 図-12 ケミカルプレストレスの予測

ここで提案した膨張コンクリートのクリープ式は, 本研究におけ るクリープ実験結果の範囲から得られた経験式であり, 厳密な適用 範囲の検証については, データの蓄積を待つ必要がある。この汎用 性の検討に関しては今後の研究課題としたい。

謝辞

本研究を実施するにあたり, 貴重なご意見を頂いた広島大学佐藤 良一教授に記して厚く謝意を表します。

\section{参考文献}

1) 日本建築学会：鉄筋コンクリート造建築物の収維ひび割れ・メカニズムと 対策技術の現状, 2003

2) 日本建築学会：鉄笳コンクリート造のひび割れ対策指針・同解説，2002

3）百瀨䝼基, 閑田徹志, 石田雅利, 桜本文敏: 膨張材及び収縮低減棛を併用 したコンクリートのひび割れ抵抗性に関する研究, 日本建築学会構造系論 文集, №. 587, pp. 7-14, 2005

4) 閑田徹志, 百瀬晴基, 桜本文钽: 膨張材と収縮低減凪を併用したコンクリ 一トによる床スラブのひび割れ低減效果に関する実験的検郡, コンクリー 卜工学年次論文集, Vol. 26, No. 1, pp. 501-506, 2004

5) 閑田徽志, 百瀬晴基, 桜本文敏, 鈴木康籍, 小田部裕一：ひび割れ低減 ンクリートの開発 (その 3〜 4), 建築学会大会梗概集, pp. 109-112, 2003 6)辻幸和：ケミカルプレストレスの推定方法について, セメント技術年報, N0. $27, \mathrm{pp} 340-344,1973$

7) SATO. R, DILGER. W. H and UJIKE. I : Deformation and Thermal Stress of Concrete Beams Constructed in Two Stages, Int. RILEM Sym. Thermal Cracking in Concrete at Early Ages, pp. 313-320, Munchen 0ct. 1994

8) コンクリート工学協会: 特集*標淮化を待つ試験方法, コンクリートエ 学, Vo123, N0. 3, pp. 55-56, 1985

9）百瀨睛基, 閉田徹志, 鈴木康範, 小林隆芳 : 低熱ポルトランドセメントと 膨張材を混入したコンクリートの膨張収縮挙動に関する研究, コンクリー 卜工学年次論文集, Vol. 26, No. 1, pp. 495-500, 2004

10) COMITE EURO-INTERNATIONAL DU BETON : CEB-FIP Model Code 90, Thomas Telford, 1990

11) ACI Committee 209 : Prediction of Creep, Shrinkage and Temperature Effects in Concrete Structures, 1982

12）土木学会, コンクリート標準示方書 [構造性能照查編], 2002

13）日本コンクリート上学協会, 自己収縮委員会報告書, 1996

14)鈴木計夫, 大野義照, 清水久博: コンクリートの乾燥收維ひび割れ発生に 関するモデル架構の拘束率, 日本建築学会近畿支部研究報告集, pp. 5-8, 1988 